\title{
Continuous and Comprehensive Evaluation (CCE) - an educational reform in Tamilnadu
}

\author{
M. B. Anitha ${ }^{1}$, Dr. A. Yuvaraj ${ }^{2}$ \\ ${ }^{I}$ (English, Research scholar, Bharathiar University,India) \\ ${ }_{2}^{2}$ (Assistant professor, English, Govt. Thirumagal Mills College, Gudiyattam, Vellore Dist, India
}

\begin{abstract}
Education plays a vital role in today's competitive world. The Government of India has taken measures to educate students at world level. As an initiative, it has formed many commissions and those commissions concentrated on the comprehension level of the learners and their maximum exposure to the practical life. As a result, government formulated scheme of evaluation called Continuous and Comprehensive Evaluation. This paper discusses some of the core issues related to the testing of English at lower elementary level.
\end{abstract}

\section{INTRODUCTION}

Education is the birth right for any individual. It is the foremost surviving tool in today's world. Since education is the back bone of a country, governments, parents, teachers and students in India give utmost importance to it comparing to any other field. Parents believe that schools will identify the latent talents of the children. According to The World Bank report (1997), India has achieved high gross enrolment rates, but low attendance and high drop out rates. Which means that a sizeable percentage of children at primary level do not complete their school education due to various reasons.

\section{ISSUES AND CHALLENGES}

In general, education at the lower primary level deals with children from 6-10 years of age. To edify the foundation in young minds, teachers should have the required qualification. They must handle the young minds with care and concern. Students at the primary level view their teachers as role model and are never skeptical of whatever teacher utters in the class room. They are good at observing things, they admire their teachers, and they try to impress teachers in different ways. As far as teaching is concerned, teachers face a few challenges in teaching the primary level students. They are under a stress to complete the portions within the stipulated time and as a result, teachers could not spend more time interacting with students which is necessary to ensure that the learners have understood the concepts taught and acquired the language skills.Majority of the teacher's time is spent on evaluating records and tests papers. Teachers of English have the responsibility to develop interest among learners but not an aversion towards the language. Students treat English as a scoring subject and hence they fail to practise it as a skill which deters an enthusiastic teacher. Issues like high drop out rates, irregular attendance, large classrooms demand immediate attention. Due to less number of qualified teachers, some schools employ unqualified teachers and that result in students' lack of understanding of concepts. Language proficiency of majority of teachers in educational institutions is not up to the mark. According to The world Bank report, (1997), children who do reach the final year of lower primary school often have low learning achievement.[1].

\section{INITIATIVES TAKEN BY THE GOVERNMENT}

Due to the issues and challenges, the government of India has formed commissions. The commissions strive hard to find solutions to the problems faced by teachers, students, academicians and parents. After independence, Indian education had a new facet. Kothari commission, 1966 was formed to improve the quality of primary education. Ravi, The Comprehensive Study of Education (2011) says that, It stated that no reform is more urgent than to transform education to endeavour to relate it to the life, needs and aspirations of the people and thereby make it a powerful instrument of social, economic and cultural transformation necessary for the realization of our national goals.[2] The Government of India has passed Compulsory education act in the year 2009. According to the department of higher education, the Right of Children to Free and Compulsory Education Act or Right to Education Act , is an Act of the Parliament of India, which describes the modalities of the importance of free and compulsory education for children between 6 and 14 years in India under Article 21 A 
of the Indian Constitution. CBSE Manual,(2009),Education aims at making children capable of becoming responsible, productive and useful members of society.[3]. The Tamilnadu government, after analyzing the major difficulties in learning, introduced a new evaluation system called Continuous and Comprehensive Evaluation, which is an alternative to traditional scheme of evaluation. CBSE Manual,(2009), Examination are an indispensable part of the educational process as some form of assessment is necessary to determine the effectiveness of teaching learning processes and their internalization by learners.[3]. The Hunter Commission (1882), Sadler commission (1917-1919), the Report of Central Advisory board/ Sargeant Plan(1944)Mudaliar commission (1952-53) were the commissions formed by the government which brought out the need for an effective system of evaluation.National Policy of Education 1986, (as cited in CBSE Manual, 2009), Continuous and Comprehensive Evaluation (CCE) scheme incorporates both scholastic and non-scholastic aspects of evaluation, spreading over the total span of instructional time. Kothari Commission, The report of the task force and status of the Board of Secondary Education(1997) advocate for the implementation of CCE. This lessens the burden and stress.[3]. According to G.O No.143 by Government of Tamilnadu, 2011, The NCF, 2005 envisions a vastly different system built upon entirely new foundations that a school-based continuous and comprehensive evaluation system be established in order to (i) reduce stress on children, (ii) make evaluation comprehensive and regular, (iii) provide space for the teacher for creative teaching, (iv) provide a tool for diagnosis and for producing learners with greater skills[4]. The Tamilnadu government implemented CCE in the academic year 2012-13 for classes I-VIII and for classes IX and X academic year 2013-14. Teacher's Manual published by government pointsout that Tamilnadu is the only state to have introduced CCE along with Tri semester pattern and subject wise activity book for primary and upper primary teachers.[5].

\section{OBJECTIVE OF CCE}

The Education department of Tamilnadu has published a hand book to teachers. In addition, it conducts training sessions to make them understand the new scheme introduced by the government. Teachers are trained to adopt different approaches and methods of teaching and testing. The Method followed in this pattern is Activity Based Learning (ABL). As per State Council of Educational Research and Training, 2014, ABL is a learner-initiated gradient.[5]. This manual acts as a guide to teachers for their professional development CCE is a combination of two assessments, Formative assessment and Summative assessment. Formative assessment comprises FA(a) and FA(b). These assessments deal with textbook exercises and given model questions. Summative assessment is based on a written test with a time schedule at the end of every tri-semester. It tests students' understanding, application of what they had studied in the class room, how creative and productive they are and their power of analysis. In a month, minimum twenty periods are allotted to subject, English. [3]. Learners need to become creative in using the language. One of the main objectives of CCE is to help learners frame sentences on their own.

\section{IMPORTANCE OF TESTING}

Students need to be tested to know their level of comprehension in concepts taught to them and to evaluate their language ability. There are major types of tests. It highlights scholastic and co-scholastic assessment. Scholastic assessment comprises formative assessment and summative assessment. Former evaluates regularly by assigning projects, activities inside the classroom and outside the classroom and the latter is conducted at the end of each tri semester. This method of assessment happens not at the end of the course but happens during the course continuously. FA(b) deals with exercises in the text book. These textual activities results in better comprehension and provide speech training. It is a paper-pen test. FA(a) deals with real life acquaintance. It emphasizes on reciting poems, is supposed to sprout with enthusiastic participation from students. It is based on activity mode. Sometimes these activities may be an extempore or one day project which connects theory and practice. It is also known as skill-based assessment. The class might be lively and interactive. During their tri semester, students are given slip test in which a single unit is included. For Class III, the questions involved are fill in the blanks, dictation words and writing answers to the questions asked. Slip test marks are considered in FA (b). It also assesses students' real life attitudes and their application of classroom learning. Incase of summative assessment, it is conducted at the end of every tri-semester. It is for 60 marks. The questions will be based on the understanding, skills, application and knowledge. Summative assessment is conducted at the end of every term. It is a blueprint-based, objective, written, individual and graded test. Each assessment would only assess the syllabus covered during that term

\section{CONCLUSION}

Any novel initiative, in the field of education, would inevitably have pros and cons, and CCE is no exception. At the initial stages, teachers, learners and parents might have faced challenges in successfully implementing this alternative method of testing. One of the major objectives of CCE is to help learners gain theoretical and practical knowledge. English being the international language of communication, it is necessary 
that learners attain minimum levels of proficiency in the language. To fulfil the objective, CCE has been implemented in schools and it is a fervent hope that learning and teaching take place in a conducive atmosphere yielding positive learning outcomes.

\section{REFERENCES}

[1] Allied publishers limited, Primary Education in India, New Delhi(1997).

[2] Ravi, S. Samuel. A Comprehensive study of Education. PHI learning private limited, New Delhi(2011)

[3] CBSE, Teacher's manual on CCE, New Delhi(2009).

[4] G. O (Ms) No. 143 dated 19.9.2011

[5] State Council of Educational Research and Training, Continuous and comprehensive evaluation, English Teachers' Manual Primary (Standard I to V)Term I, Chennai.

[6] Dr. Manjula P. Rao and Dr. Purushothaman rao T. NCERT. Effectiveness of Continuous and Comprehensive Evaluation over the evaluation practices of Teachers.

[7] State Council Of Educational Research and Training, Continuous and comprehensive evaluation general guidelines primary classes $I-V$ (2014).

[8] Ajit mondal and Jayanta mete , Issues And Ideas In Education vol.1 No.2 September 2013 pp. 121-138.

[9] Dr. Usha Dutta, Dr. Neeru Bala, Teaching of English at primary level in government schools, synthesis Report, Sarva Siksha Abhiyan, National Council of Educational Research \& Training. New Delhi(2012) 